aids. However, educating institutions quite often lack expertise in the system-operational approach. As a corollary they do not justify the expectations held by students, employers and the society as a whole to get access to contemporary education. Such an antinomy is likely to occur when advances in integral elements do not obligatory ensure attainment of the so called synergistic effect in absence of an educative model that is based on control of key operational processes within high schools. This is why the implementation of quality control system is expected to produce a due effect for all essential components to their activity.

The present article addresses the issue of the quality of education and the quality of educational services within a control system, while the said quality is based on a system-operational approach, i.e. when the needs by both customers (employers), and other interested parties are given full account for. Specifically, such an interaction between process and gradual performance augmenting techniques becomes one of the useful tools for further development of higher schools and, undoubtedly, is supposed to raise up graduating quality levels, the graduating students' high competitiveness and mobility within labor markets.

\title{
References
}

1. Natsionalnyi standart Ukrainy, 2009. DSTU ISO 9001:2009. Systemy upravlinnia yakistiu. Vymohy (ISO 9001:2008). Kyiv: Derzhspozhyvstandart Ukrainy.

2. Iakymenko, Yu.I., red., Uholnikov, V.Iu. ta Yarovyi, O.V. ukl., 2012. Metodychni vkazivky shchodo rozroblennia materialiv $z$ akredytatsii

napriamiv pidhotovky ta spetsialnostei. Kyiv: IVTs "Vydavnytstvo «Politekhnika»".

3. Dmytrychenko, M.F. ta in., 2013. Fundamentalizatsiia profesiinoi pidhotovky $u$ vymiri Yevropeiskoho osvitianskoho prostoru, Kyiv: NTU.

УДК 355.233-052:17.022.1-027.561 (477)

https://doi.org/10.32835/2223-5752.2018.16.49-55.

\section{ПРОФЕСІЙНО-ЦІННІСНІ ОРІЕНТАЦІЇ МАЙБУТНІХ ФАХІВЦІВ ВІЙСЬКОВОГО УПРАВЛІННЯ ЗБРОЙНИХ СИЛ УКРАЇНИ}

Ірина Роман,

ад 'юнкт, Львівський державний університет безпеки жсттєдіяльності

ORCID: 0000-0001-6691-3994

ResearcherID: V-7969-2018

e-mail:romaniryna@yahoo.com

\section{КЛЮЧОВІ СЛОВА:}

професійні ціннісні орієнтації, метод компетентних суддів, фахівці військового управління, майбутні офіцери, мотиваційно-ціннісна сфера особистості, Збройні сили України
Реферат

У статті представлено результати дослідження професійно-ціннісних орієнтацій майбутніх фахівців військового управління Збройних сил України. 3'ясовано, що їх формування у курсантів військових закладів вищої освіти $\epsilon$ актуальною проблемою професійної педагогіки. На це вказують і результати аналізу практики професійної підготовки офіцерів Збройних сил України, що характеризується об’єктивними суперечностями. Результати аналізу наукової літератури свідчать, що ця проблема належним чином не висвітлена у працях науковців. Лише окремі ії аспекти знайшли своє відображення в публікаціях.

Встановлено, що науковці використовують різні підходи та індикатори для виокремлення ціннісних орієнтацій, що відносяться до професійних. Залежно від змісту професійної діяльності, перелік ціннісних орієнтацій також відрізняється. Тому, з метою виокремлення професійних ціннісних орієнтацій майбутніх фахівців військового управління Збройних сил України, емпіричним шляхом опитано 149 респондентів - офіцерів Збройних сил України та науково-педагогічних працівників військових закладів вищої освіти. За допомогою методу компетентних суддів сформовано перелік професійно-ціннісних орієнтацій майбутніх фахівців військового управління, які у структурі ціннісномотиваційної сфери особистості майбутнього фахівця військового управління Збройних сил України займають особливе місце. 3'ясовано, що до основних професійно-ціннісних орієнтацій майбутніх фахівців військового управління можна віднести: вірність Вітчизні, відданість українському народові та військовій справ; військову честь і офіцерську гідність; особисту причетність і відповідальність за долю країни, за їі безпеку; самореалізацію і кар'єру. 
Постановка проблеми. Формування професійних ціннісних орієнтацій майбутніх фахівців військового управління у військових закладах вищої освіти є актуальною проблемою професійної педагогіки. Ціннісні орієнтації $\epsilon$ найважливішими елементами внутрішньої структури особистості офіцера та соціальної групи (військового підрозділу, колективу), що відмежовують значиме, суттєве від вторинного через систему імперативів, регуляторів, орієнтирів соціальних дій. Ступінь розвитку ціннісних орієнтацій - ознака зрілості особистості, усвідомлення нею вагомості інтеграції між членами соціальної групи або організації. Кожен підрозділ як мікроструктура Збройних сил України має свою систему сталих, найбільш прийнятних формальних та неформальних правил і норм діяльності, звичаїв і традицій, індивідуальних та групових інтересів, ціннісних орієнтацій. Це визначає поведінку персоналу, їхню задоволеність умовами служби, рівень взаємного співробітництва і сумісності, перспективи спільного колективного розвитку. Крім того, важливе значення мають особливості професійної культури, професійні ціннісні орієнтації офіцерів, зумовлені рівнем сформованості загальної і професійної культури в армійському середовищі. Суперечливість у ціннісних орієнтаціях дезорганізує функціонування будь-якої організації, породжує непослідовність у поведінці та поглядах іï членів, що є неприпустимим для підрозділів ЗСУ. Нерозвиненість ціннісних орієнтацій ознака соціального інфантилізму, панування зовнішнього середовища над інтересами особистості, соціальної групи або організації загалом, що також не може бути прийнятним для військової організації. Особливе значення мають професійні ціннісні орієнтації, оскільки діяльність у єдиному ціннісно-орієнтаційному полі збагачує і організацію, і їі членів за рахунок синергетичного ефекту. Виникає середовище, яке характеризують єдина місія, єдина мета, єдині завдання.

Про актуальність формування професійних ціннісних орієнтацій майбутніх фахівців військового управління свідчать і результати аналізу практики професійної підготовки офіцерів Збройних сил України у військових закладах вищої освіти, яка характеризується об'єктивними суперечностями, зокрема, між нагальною потребою суспільства у професійно підготовлених, згуртованих офіцерах і реальним станом сформованості їхньої корпоративної культури та професійних ціннісних орієнтацій; між потенційними можливостями сучасної вищої військової школи для ефективного формування професійних цінностей, норм, традицій i культури у майбутніх фахівців і недостатнім використанням цих можливостей на практиці.

Про нагальну необхідність підвищення у фахівців Збройних сил України корпоративного духу та сформованості ціннісних орієнтацій свідчать й емпіричні результати дослідження, зокрема, опитування випускників ВЗВО, а також непоодинокі факти протиправних дій персоналу Збройних сил України, скоєння ними правопорушень і злочинів, що зумовлено низьким рівнем сформованості професійних ціннісних орієнтацій, моральної свідомості та недостатньою обізнаністю 3 вимогами корпоративної культури.

Аналіз наукових праць. Результати аналізу наукової літератури свідчать, що проблема формування професійних ціннісних орієнтацій майбутніх фахівців військового управління належним чином не висвітлена у працях науковців. Окремі iї аспекти знайшли своє відображення в публікаціях С. Дермельової (2005) (визначила особливості формування професійно-ціннісних орієнтацій курсантів вищого військового навчального закладу), Ю. Горбенка (2006) (дослідив основні чинники, що впливають на становлення ціннісних орієнтацій військовослужбовців у процесі професійної підготовки), П. Кукси (2003) (дослідив особливості формування ціннісних орієнтацій і установок у курсантів військових навчальних закладів у процесі виховання та навчальної діяльності), Т. Новікової (2013) (дослідила процес формування соціокультурних цінностей майбутніх офіцерів-прикордонників у процесі вивчення гуманітарних дисциплін) та В. Полюги (2006) (дослідив динаміку ціннісних орієнтацій військовослужбовців строкової служби), В. Матвійчук (2009) (обгрунтував педагогічну технологію формування ціннісних орієнтацій у майбутніх офіцерівприкордонників).

Метою статті $\epsilon$ дослідження професійноціннісних орієнтацій у структурі ціннісномотиваційної сфери особистості майбутнього фахівця військового управління Збройних сил України. 
Виклад основного матеріалу. Дослідження професійно-ціннісних орієнтацій майбутніх фахівців військового управління Збройних сил України є важливим для визначення та обгрунтування педагогічних умов їхнього ефективного формування у процесі професійної підготовки у військових закладах вищої освіти. Важливо також з'ясувати, які групи ціннісних орієнтацій мають значення у професійній підготовці майбутніх офіцерів, а також які чинники впливають на становлення ціннісномотиваційної сфери особистості майбутніх фахівців військового управління. 3 цією метою узагальнено наявний досвід, представлений в наукових працях, виконаних у попередні роки.

Так, наприклад, С. Соловйов (1996) виокремлює військово-корпоративні, військовопрофесійні, пізнавально-розвиваючі, спеціальномеркантильні та матеріально-побутові цінності. Така класифікація для нас представляе певний інтерес, однак не можемо погодитися 3 автором про доцільність формування у процесі професійної підготовки спеціальномеркантильних i матеріально-побутових ціннісних орієнтацій.

Дещо іншу класифікацію представляє В. Мартинюк (2006, с. 11), який вважає, що підставами для «класифікації ціннісних орієнтацій військовослужбовців повинні бути: рівень усвідомлення (усвідомлені та неусвідомлені ціннісні орієнтації); рівень сформованості (ціннісні орієнтації науково-теоретичного та буденно-емпіричного рівнів сформованості); спрямованість (матеріальні, соціальні, політичні, духовні та військово-професійні орієнтації); суб'єкти ціннісних орієнтацій (ціннісні орієнтації військовослужбовців строкової служби; ціннісні орієнтації військовослужбовців рядового і сержантського складу, що проходять військову службу за контрактом; ціннісні орієнтації офіцерського складу); ступінь загальності (загальнолюдські ціннісні орієнтації, ціннісні орієнтації українського суспільства, корпоративні ціннісні орієнтації військовослужбовців, особисті ціннісні орієнтації); ступінь сталості (мінливі й сталі ціннісні орієнтації); місце та роль у процесі життєдіяльності (ситуаційні, поточні, службовопрофесійні та перспективні ціннісні орієнтації)». Такий підхід $\epsilon$ прийнятним i абсолютно виправданим. Спираючись на запропоновану класифікацію, доцільно виокремити військово-професійні орієнтації (за критерієм спрямованості), що належать офіцерському складу (майбутнім фахівцям військового управління) за критерієм - суб'єкти ціннісних орієнтацій. При цьому за ступенем загальності вони $€$ корпоративними ціннісними орієнтаціями військовослужбовців, а за критерієм сталості сталими.

Також погоджуємося 3 В. Мартинюком у тому, що професійні ціннісні орієнтації в системі ціннісних орієнтацій військовослужбовців займають особливе місце і є специфічними, оскільки, на відміну від інших ціннісних орієнтацій, вони не лише містять у собі професійно-технологічну спрямованість, a $є$ своєрідним синтезом й інтегративним утворенням матеріальних, соціальних, політичних i духовних ціннісних орієнтацій (Мартинюк, 2006, с. 12).

Для з'ясування того, які саме ціннісні орієнтації у структурі ціннісно-мотиваційної сфери особистості майбутнього фахівця військового управління Збройних сил України належать до професійних, заслуговує на увагу дослідження В. Матвійчука (2009), у якому він обгрунтовує педагогічну технологію формування ціннісних орієнтацій у майбутніх офіцерів-прикордонників. Дослідник вважає, що до змісту ціннісних орієнтацій майбутніх офіцерів доцільно віднести ті, що стосуються сфери державності, демократії та моральності. На нашу думку, такий підхід дещо розмиває класифікаційні межі тих ціннісних орієнтацій, які належать суто до професійних. Так, наприклад, за В. Матвійчуком, до цінностей у сфері державності належать демократичний суспільний устрій України, заснований на ідеї соціальної справедливості; суверенітет та територіальна цілісність України; вірність Конституції України та іiі законам; економічні, соціальні, політичні, духовні інтереси українського народу, його життя, свобода й незалежність; дбайливе ставлення до звичаїв та традицій предків, вітчизняної історії (Матвійчук, 2009, с. 6-7).

До цінностей, що мають сповідуватися майбутніми офіцерами у сфері демократії, дослідник відносить рівність усіх людей перед законом; невід'ємне реальне право на справедливість та щастя; пошана до суверенітету країн світу, їх національної самобутності; товариство, партнерство 3 прикордонниками суміжних 3 Україною країн; здійснення соціального й правового захисту громадян, які 
перетинають державний кордон (Матвійчук, c. 7].

У сфері моральності до основних цінностей майбутніх офіцерів, за В. Матвійчуком, належать любов до своєї Батьківщини, рідного народу; вірність Військовій присязі, конституційному обов'язку; дотримання честі й гідності прикордонника; бездоганна службова репутація; пошана до старших за посадою, військовим званням та віком $(2009$, с. 7$)$.

Однак нам імпонує висновок В. Матвійчука, відповідно до якого «специфіка ціннісних орієнтацій майбутніх офіцерів-прикордонників зумовлена їхнім призначенням - бути всебічно підготовленими до виконання завдань 3 охорони та захисту державного кордону України, визначених керівними документами, що регламентують службову діяльність ДПСУ (2009, с. 7). Процес формування ціннісних орієнтацій у курсантів має характерні особливості, які виявляються у недоліках зазначеного процесу та чинниках, що впливають на нього. Ціннісні орієнтації курсантів формуються лише в умовах навчально-виховного процесу НАДПСУ та під час стажувань в органах охорони ДКУ».

Отже, результати узагальнення висновків наукових праць 3 проблеми дослідження дають змогу зробити висновок, що науковці використовують різні підходи та індикатори для виокремлення ціннісних орієнтацій, котрі відносяться до професійних. Залежно від змісту професійної діяльності, перелік ціннісних орієнтацій також відрізняється. Тому 3 метою виокремлення професійних ціннісних орієнтацій емпіричним шляхом респондентам було запропоновано скласти їх перелік. Респондентами було обрано 55 офіцерів частин і підрозділів ЗСУ, 54 викладачі Національної академії сухопутних військ імені гетьмана Петра Сагайдачного, 34 викладачі Національного університету оборони України імені Івана Черняховського та 6 викладачів Військової академії (м. Одеса) (кафедра гуманітарних та соціально-економічних дисциплін). Їм було запропоновано визначити 10 ціннісних орієнтацій, які, на їхню думку, належать до професійних. У результаті опрацювання 149 анкет було виокремлено ціннісні орієнтації, що більше 5 разів зазначалися респондентами в анкетах.

Однак, у результаті аналізу наведених формулювань, стало очевидним, що серед ціннісних орієнтацій, зазначених респондентами, трапляються такі, які не узгоджуються 3 попередніми теоретичними висновками щодо суті і змісту професійних ціннісних орієнтацій. Так, наприклад, респонденти до таких ціннісних орієнтацій відносять певною мірою меркантильні твердження: гарантовано отримувати грошове утримання; матеріально забезпечувати сім>ю; можливість матеріально забезпечити родину та вирішити житлову проблему; прагнення в умовах соціально-економічної нестабільності суспільства уникнути безробіття; бажання, незалежно від економічних потрясінь, що відбуваються в державі, гарантовано отримувати заробітну плату (грошове утримання), бути працевлаштованим; прагнення до отримання безкоштовної освіти тощо. 3 огляду на це, нами було застосовано один 3 методів експертної оцінки - метод компетентних суддів. Використання цього методу передбачало залучення компетентних фахівців, зокрема 15 експертів, які мали досвід роботи в аналогічних експертизах та позитивно ставились до участі в експерименті.

До групи експертів увійшли начальники, професори i доценти кафедр моральнопсихологічного забезпечення діяльності військ, гуманітарних наук, тактики підрозділів бойового (оперативного) забезпечення, іноземних мов та військового перекладу; управління повсякденною діяльністю військ та тилового забезпечення; фізичного виховання, спеціальної фізичної підготовки і спорту.

Метою застосування методу компетентних суддів було виокремлення 3 переліку ціннісних орієнтацій, наведених респондентами, таких тверджень, які дійсно мають характер професійно-ціннісних орієнтацій майбутніх фахівців військового управління. Для цього експертам було запропоновано вказати ранг тим ціннісним орієнтаціям (найбільш важлива - 10 балів, не важлива - 0 балів), які найбільше стосуються професійного середовища майбутніх фахівців військового управління.

У результаті застосування методу компетентних суддів було сформовано перелік професійно-ціннісних орієнтацій майбутніх фахівців військового управління. У таблиці 1 представлено розподіл за значимістю та кількість балів, що їх було виставлено експертами професійним ціннісним орієнтаціям, представленим для ранжування. 
Таблиця 1

Перелік професійно-ціннісних оріснтацій, необхідних для ефективної професійної діяльності майбутнім фахівцям військового управління (після ранжування експертами за десятибальною системою)

\begin{tabular}{|c|c|c|}
\hline $\begin{array}{l}\text { № } \\
\text { 3/II }\end{array}$ & Професійні ціннісні орієнтації & Бали \\
\hline 1 & Вірність Вітчизні & 9,55 \\
\hline 2 & $\begin{array}{l}\text { Бути представником ЗС держави, який стоїть на сторожі інтересів } \\
\text { українського народу }\end{array}$ & 9,32 \\
\hline 3 & Відданість українському народові та військовій справі & 8,44 \\
\hline 4 & Повага до військових ритуалів & 7,55 \\
\hline 5 & Причетність до продовження військових традицій Української армії & 7,21 \\
\hline 6 & Військова честь і офіцерська гідність & 6,85 \\
\hline 7 & Особиста причетність і відповідальності за долю країни, за їі безпеку & 6,45 \\
\hline 8 & $\begin{array}{c}\text { Володіння та експлуатація сучасних систем озброєння } \\
\text { автоматизованих систем управління }\end{array}$ & 5,25 \\
\hline 9 & Самореалізація і кар’єра & 5,17 \\
\hline 10 & $\begin{array}{l}\text { Владні повноваження щодо управління (командування) підрозділом } \\
\text { (колективом) }\end{array}$ & 4,75 \\
\hline 11 & Особливі умови професійної діяльності & 4,25 \\
\hline 12 & Особиста причетність до захисту Вітчизни & 4,00 \\
\hline 13 & Професійна та управлінська компетентність & 3,75 \\
\hline 14 & Вірність Військовій присязі, конституційному обов'язку & 3,25 \\
\hline 15 & Військове товариство, причетність до військового колективу & 3,00 \\
\hline 16 & Військова форма та однострій & 2,75 \\
\hline
\end{tabular}

Висновки. Формування професійних ціннісних орієнтацій майбутніх фахівців військового управління у ВЗВО $є$ актуальною проблемою професійної педагогіки. На це вказують і результати аналізу практики професійної підготовки офіцерів Збройних сил України у військових закладах вищої освіти, яка характеризується об'єктивними суперечностями. Результати аналізу наукової літератури свідчать, що ця проблема належним чином не висвітлена у працях науковців. Лише окремі ії аспекти знайшли своє відображення у публікаціях. У результаті застосування методу компетентних суддів було сформовано перелік професійно-ціннісних орієнтацій майбутніх фахівців військового управління, які у структурі ціннісно-мотиваційної сфери особистості майбутнього фахівця військового управління Збройних сил України займають особливе місце.

Перспективами подальших наукових розвідок $є$ визначення критеріїв, показників $\mathrm{i}$ рівнів сформованості професійно-ціннісних орієнтацій майбутніх фахівців військового управління, а також визначення і обгрунтування педагогічних умов їх ефективного формування.

\section{Література}

1. Горбенко, Ю. Л., 2006. Особливості становлення иіннісних орієнтацій у процесі професійної підготовки військовослужбовиів.
Кандидат наук. Ін-т психології ім. Г. С. Костюка АПН України. Київ.

2. Дермелева, Е. В., 2005. Специфика 
формирования профессионально-ценностных ориентаций курсантов высшего военного учебного заведения. Кандидат наук. Смол. гос. пед. ун-т. Смоленск.

3. Кукса, П. А., 2003. Формирование ценностных ориентаций и установок $у$ курсантов военных вузов в процессевоспитания u учебной деятельности. Кандидат наук. Санкт-Петербург.

4. Новікова, Т. Л. 2013., Формування соціокультурних цінностей майбутніх офіцерів-прикордонників у прочеесі вивчення гуманітарних дисичилін. Кандидат наук. Нац. акад. Держ. прикордонної служби України ім. Б. Хмельницького. Хмельницький.

5. Полюга, В. А., 2006. Динаміка ціннісних орієнтаичій військовослужбовичів строкової служби. Кандидат наук. Київ. нац. ун-т ім. Т. Шевченка. Київ.

6. Мартинюк, В. М., 2006. Ціннісні орієнтації військовослужбовців збройних сил України (сочіально-філософський аналіз). Кандидат наук. Харківський ун-т Повітряних Сил ім. Івана Кожедуба. Харків.

7. Матвійчук, В. П., 2009. Педагогічна технологія формування ціннісних орієнтацій у майбутніх офіиерів-прикордонників. Кандидат наук. Нац. акад. Держ. прикордонної служби України ім. Б. Хмельницького. Хмельницький.

8. Соловьев, С. С., 1996. Трансформация ценностей военной службы. Социологические исследования, 9, 160 с.
KEY WORDS: professional value orientations, competent judges method, military management specialists, future officers, a person's motivational value sphere, the Armed Forces of Ukraine
Abstract

\section{Professional value orientations of future mulitary managment specialists of the Armed Forces of Ukraine}

Iryna Roman,

postgraduate student, Lviv State University of Life Safety

The article deals with the results of the research concerning professional value orientations of future military management specialists in the Armed Forces of Ukraine. It is explained that formation of these orientations is the challenging issue for cadets and for professional pedagogy. It is proved by the analysis results of officers' professional training in the Armed Forces of Ukraine which is described being rather contradictive. The results of scientific literature survey suggest that this problem is not reasonably studied in research works. Only some aspects of this problem are depicted in publications.

It is found out that scientists use various approaches and indicators for separating value orientations which are supposed to be professional ones. Depending on professional activity content, the list of value orientations can differ as well. Therefore, 149 responders (officers of the Armed Forces of Ukraine and scientific-pedagogical workers in military institutions of higher education) have been interviewed by empirical approach aimed on selecting and separating the professional value orientations of future military management specialists of the Armed Forces of Ukraine. With the help of competent judges it became possible to form the list of future military management specialists' professional value orientations, which is important in the value-based motivation sphere of a personality of future military management specialists of the Armed Forces of Ukraine. It is made definite that future military management specialists' main professional value orientations are the following: commitment to the Motherland, faithfulness to Ukrainian nation and profession, military honor and officer's dignity, personal involvement and responsibility for the country, its defense, self-realisation and career.

\section{References}

1. Horbenko, Yu. L., 2006. Osoblyvosti stanovlennia tsinnisnykh oriientatsii u protsesi profesiinoi pidhotovky viiskovosluzhbovtsiv. Kandydat nauk. In-t psykholohii im. H. S. Kostiuka APN Ukrainy. Kyiv.

2. Dermeleva, E. V., 2005. Spetsyfyka formyrovanyia professyonalno-tsennostnykh oryentatsyi kursantov vyssheho voennoho uchebnoho zavedenyia. Kandydat nauk. Smol. hos. ped. in-t. Smolensk.

3. Kuksa, P. A., 2003. Formyrovanye tsennostnykh oryentatsyi y u,stanovok u kursantov voennykh vuzov v protsesse vospytanyia y uchebnoi deiatelnosty. Kandydat nauk. Sankt-Peterburh.

4. Novikova, T. L., 2013. Formuvannia sotsiokulturnykh tsinnostei maibutnikh 
ofitseriv-prykordonnykiv u protsesi vyvchennia humanitarnykh dystsyplyn. Kandydat nauk. Nats. akad. Derzh. prykordonnoi sluzhby Ukrainy im. B. Khmelnytskoho. Khmelnytskyi.

5. Poliuha, V. A., 2006. Dynamika tsinnisnykh oriientatsii viiskovosluzhbovtsiv strokovoi sluzhby. Kandydat nauk. Kyiv. nats. un-t im. T. Shevchenka. Kyiv.

5. Martyniuk, V. M., 2006. Tsinnisni oriientatsii viiskovosluzhbovtsiv zbroinykh syl Ukrainy (sotsialno-filosofskyi analiz). Kandydat nauk.
Kharkivskyi un-t Povitrianykh Syl im. Ivana Kozheduba. Kharkiv.

6. Matviichuk, V. P., 2009. Pedahohichna tekhnolohiia formuvannia tsinnisnykh oriientatsii u maibutnikh ofitseriv-prykordonnykiv. Kandydat nauk. Nats. akad. Derzh. prykordonnoi sluzhby Ukrainy im. B. Khmelnytskoho. Khmelnytskyi.

7. Solovev, S. S., 1996. Transformatsyia tsennostei voennoi sluzhby. Sotsyolohycheskye yssledovanyia, $9,160 \mathrm{~s}$.

УДК 377/378:656.7]:37.091.33

https://doi.org/10.32835/2223-5752.2018.16.55-61.

\section{ПРОБЛЕМНЕ НАВЧАННЯ В ПРОФЕСІЙНІЙ ПІДГОТОВЦІ ДИСПЕТЧЕРІВ УПРАВЛІННЯ ПОВІТРЯНИМ РУХОМ}

Оксана Данилко,

кандидат педагогічних наук,

доиент кафедри інформаційних технологій та обслуговування повітряного руху

Льотної академії Національного авіаційного університету

ORCID: 0000-0002-7942-8012

e-mail:monyasolnce@gmail.com

\section{Катерина Суркова,}

кандидат педагогічних наук, доцент,

доцент кафедри інформаційних технологій та обслуговування повітряного руху

Льотної академії Національного авіаційного університету

ORCID: 0000-0002-1388-7611

e-mail:eskirua@gmail.com

\section{КЛЮЧОВІ СЛОВА:}

Проблемне навчання, професійна діяльність та підготовка диспетчерів управління повітряним рухом, рівні навчальних досягнень, практичні завдання проблемного типу
Реферат

У статті проаналізовано наукові досягнення теорії та практики проблемного навчання до професійної підготовки диспетчерів управління повітряного руху. Актуальність даної теми обумовлюється недостатньою адаптацією та розробленістю деяких положень проблемного навчання відносно підготовки майбутніх диспетчерів управління повітряного руху як фахівців операторського профілю. Розглянуто психологічні основи проблемного навчання та описано фактори, що впливають на складність проблемного завдання. Подано структуру організації проблемного навчання в процесі теоретичної підготовки авіаційних операторів. Описано групи методів навчання та професійної підготовки авіаційних фахівців. Розглянуто деякі професійноорієнтовані дисципліни, які є основою для якісного виконання професійних завдань при обслуговуванні повітряного руху та які входять в систему професійної підготовки диспетчерів управління повітряного руху, складовими якої є теоретична (дотренажерна) та тренажерна підготовка. На основі цього встановлено, що на даний час недостатньо використовуються наукові досягнення з проблемного навчання, що потребує доопрацювання. Виділено чотири рівні навчальних досягнень курсантів в процесі розв'язання проблемних ситуацій: низький, середній, достатній і високий. Подано компоненти проблемних завдань, такі як: умови проблемної ситуації, проблема, розв'язок проблеми, критерії оцінювання прийнятих рішень. Акцентовано увагу на перевагах проблемного навчання як можливостях для розвитку професійно-важливих якостей майбутніх авіадиспетчерів, а саме: уваги, пам'яті, спостережливості, активізації мислення, активізації пізнавальної діяльності, самостійності, відповідальності, критичності і самокритичності, ініціативності, нестандартності мислення, обережності і рішучості тощо. Показано, що якісне застосування отриманих професійних знань і грамотне рішення виробничих завдань в різних умовах діяльності залежить від використання завдань проблемного типу в професійній підготовці диспетчерів управління повітряного руху. Такі завдання забезпечують формування у курсантів достатнього і високого рівнів навчальних досягнень, які відповідають ступеню застосування і творчості в майбутній професійній діяльності. 